投球動作のステップ脚における接地位置の違いが肩関節の負荷に与える影響

ー 平地とマウンドの比較 -

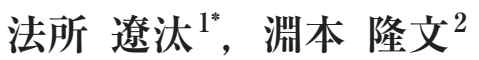

\title{
Variations in shoulder loading due to differences in the site of stepping foot contact during baseball pitching - Comparison between flat ground and mound conditions -
}

\author{
Ryota Hosho $^{1^{*}}$ and Takafumi Fuchimoto ${ }^{2}$ \\ ${ }^{1}$ 医療法人清翠会牧整形外科病院， $=536-0008$ 大阪府大阪市城東区関目 6-15-30 (Medical Corporation Seisuikai Maki Or- \\ thopedic Hospital, 6-15-30 Sekime, Joto-ku, Osaka, Osaka 536-0008, Japan) \\ ${ }^{2}$ 大阪体育大学， =590-0496 大阪府泉南郡熊取町朝代台1-1 (Osaka University of Health and Sport Sciences, 1-1 Asashiro- \\ dai, Kumatori-cho, Sennan-gun, Osaka 590-0496, Japan)
}

Received : February 19, 2019 / Accepted: August 16, 2019

\begin{abstract}
This study examined variations in shoulder loading due to differences in the site of stepping foot contact during baseball pitching, while comparing flat ground and mound conditions. Measurement was performed, involving 10 right-handed pitchers who belonged to university baseball clubs, under original flat ground and mound conditions. Pitching movements were classified into 3 categories: [normal], [narrow], and [outside]. Through 3-dimensional motion analysis using a motion capture system, the following results were obtained: 1 . The pitching velocity was significantly higher in the [normal] compared with [narrow] and [outside] conditions and under the mound compared with flat ground condition. 2. The peak torque of the shoulder internal rotation was markedly lower in the [narrow] compared with [normal] condition. There were no significant differences between the [normal] and [outside] conditions or between the flat ground and mound conditions. 3. The posterior, superior, and inferior shearing forces, as well as the proximal traction force, which influence the humeral head of the shoulder, were markedly greater in the [normal] compared with [narrow] and [outside] conditions. The anterior and posterior shearing forces and proximal traction force were significantly greater under the mound compared with flat ground conditions. Based on the results, the internal rotation torque of the shoulder, as well as the shearing and traction forces influencing the humeral head of the shoulder, may vary due to differences in the site of stepping foot contact during baseball pitching and between flat ground and mound conditions. The former may also be useful to prevent pitching-related shoulder injuries.
\end{abstract}

Jpn J Phys Fitness Sports Med, 68(6): 397-406 (2019)

Keywords : throwing shoulder injuries, 3-dimensional motion analysis, internal rotation torque, shearing forces

\section{緒言}

野球選手に多い障害の一つとして, 投球障害肩がある。 近年, 動力学的な視点から投球動作中に発生する肩関節 の負荷について検討されており，投球障害肩との関連性 についても報告されている ${ }^{1-4)}$. Fleisig et al. ${ }^{1)}$ は, 最大 外旋位直前に危険度の高い瞬間があり, 肩関節では 67

*Correspondence: hou09p037@yahoo.co.jp
$\mathrm{Nm}$ の内旋トルクと $310 \mathrm{~N}$ の前方剪断力が生じると報告 している. 宮西ら ${ }^{5)}$ は, フォロースルー期に肩関節が内転・ 内旋位になると同時に, 上腕骨頭が上方に移動する力に よって肩峰下インピンジメント症候群が引き起こされる 可能性があると示唆している。 そして，投球障害肩は後 期コッキング期（足底接地から肩関節最大外旋位）から 加速期（肩関節最大外旋位からボールリリース）にかけ て生じる肩関節外旋および内旋運動に伴って症状を呈す ることが多い ${ }^{6,7)}$ ことから，投球動作中に発生する肩関 
節の負荷の中でも，特に肩関節内旋トルクの值が肩関節 の負荷を示す指標の一つとして挙げられる ${ }^{8)}$.

一方で，投球障害肩が発生する原因の一つとして，下 肢から生じる運動連鎖が上手く行われないことが言われ ている ${ }^{7)}$. 松尾ら ${ }^{9)}$ は, 肩関節や肘関節の障害予防のた めには, 着地からボールリリースにかけてのステップ脚 への加重といった下肢動作が重要であると述べている. Davis et al. ${ }^{10)}$ は, ステップ脚が開いて接地することで体 幹の回旋が早くなると, 過度な肩関節水平伸展が生じ, 肩関節の傷害につながると報告している。また，ステッ プ脚が狭い位置では, 投球フォームが不安定となること や体幹の異常な運動が引き起こされることが言われてい る ${ }^{11,12)}$. 投球動作は全身運動であると言われており ${ }^{6)}$, 下肢の並進運動の後に身体各部分の回転や回旋運動が顕 著となる ${ }^{13)}$ 。このことから, 投球動作中に発生する肩関 節の負荷は, 下肢の運動の影響を受けると推察され，そ れを定量的に検討することで投球障害肩の予防につなが る知見が得られると考えられる。しかしながら，投球動 作におけるステップ脚の接地位置を変えることに対し, 動力学的な視点から検討した研究は上記以外に見当たら ない，そこで本研究の前段階として，平地にてステップ 幅拉よびステップ方向を変えることが肩関節の負荷に与 える影響について検討した結果，ステップ幅を通常より も狭くした位置とステップ方向を通常よりも外側にした 位置に㧍いて, 通常と同等の負荷が生じることが示唆さ れた ${ }^{14)}$. 本研究では, より実戦に近付けるために, 自作 の平地とマウンドを使用し，投球動作を行わせた。そし て, 平地とマウンドの環境要因, ステップ脚の接地位置 を通常の位置, 通常よりも狭い位置, 通常よりも外側の 位置に分けた動作要因の違いにより, 肩関節における上 腕骨頭に作用する剪断力および铱引力と肩関節内旋卜ル クがどのような影響を受けるのかを検証しようとした。

\section{方 法}

被験者 被験者は, 体育大学の硬式野球部に所属する投
手の中でも，最高球速が $130 \mathrm{~km} / \mathrm{h}$ 以上の右投げ男子 10 名 (年齢 $20.3 \pm 1.1$ 歳, 身長 $176.1 \pm 5.8 \mathrm{~cm}$, 体質量 $73.4 \pm 8.8$ $\mathrm{kg})$ で, 過去に肩関節障害の既往のない者とした，本研 究は大阪体育大学倫理委員会の承認を得た（承認番号 17 -10)。な扮, 被験者には, 事前に本研究の目的や測定内 容および測定時の危険性について説明し，同意を得た。

自作の平地床およびマウンド 本研究は, 自作の平地床 とマウンドを使用して行った。平地床に関しては, 市販 の構造用合板にスポーツタイプの人工芝 (ユニチカ社製) を貼付し作成した（Fig. 1)，マウンドに関しては，公認 野球規則 ${ }^{15)}$ に定められている通りに，投手板の前方 15.2 $\mathrm{cm}$ の地点から, 本祵に向かって182.2 $\mathrm{cm}$ の地点まで, $30.5 \mathrm{~cm}$ につき $2.5 \mathrm{~cm}$ 下がる傾斜をつけ, 市販の構造用 合板と木材を組み合わせて作成した。 またマウンドの表 面には，平地床と同様の人工芝を貼付した（Fig. 1）。

実験手順 測定は屋内に自作の平地床とマウンドを設置 して行い，測定した動作はセットポジションからの投球 動作とした.

動作条件の規定は, 平地床とマウンドのそれぞれに テープを貼ることによって行った（Fig. 2)。平地床に関 して，まず基準点を定め，基準点を通る基準線(1)を設定 した，次に，基準点から基準線(1)垂直となる基準線(2) を引いた，そして，被験者には，軸脚となる右足関節（内 果と外果を結ぶ線の中点）が基準点上に位置し，爪先が 基準線(1)上に位置するセットポジションの姿勢をとらせ た。マウンドに関しても平地と同様に設定したが，基準 線(1)は投手板の前縁とし，その中心を基準点とした。 ま た，投手板への右足の置き方は被験者自身が最も投げや すいように調整し，条件間で変化がないよう規定した。

次に，的の位置を設定するために，まず被験者全員に 平地床およびマウンドにてネットへの投球を 1 試技ずつ 行わせた。この際被験者には, 基準線(2)の方向の 18.44 m先にホームベースがあることを想定させ, ホームベー

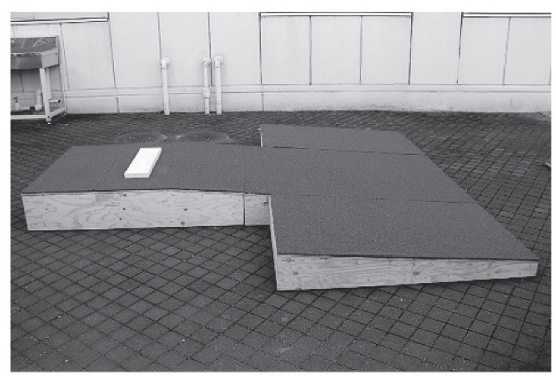

Fig. 1 The original flat ground and mound conditions used in pitching. For the flat ground, a sports type artificial turf was stuck on a commercially available plywood for construction. Mounds were made by combining commercially available structural plywood and wood as stipulated in the official certification of baseball. 
ス上の中央でベルトの高さ（床から約 $70 \mathrm{~cm}$ ）に向かっ てボールを投げることをイメージさせ，基準点から 4.6 $\mathrm{m}$ 先に設置したネットに向かって硬式の野球ボールを全 力で投げさせた。そして，ボールリリース時のボールの 座標值（以下，ボールリリース位置）およびボール速度 を算出し，ボールリリース位置からホームベース上に向 かう軌跡の間で, $4.6 \mathrm{~m}$ 先のネットを通過する位置を算 出し，そこに的（0.3 m四方）を設置した（Fig. 3).

動作条件は, 平地とマウンドのそれぞれに対し, [通常] [狭い］［外］の 3 条件とした。［通常］は, 被験者が最 も投げやすい方法で行った［狭い］では，基準線(2)上 に基準点からの距離が下肢長（右上前腸骨棘と右脛骨内 果を結ぶ線）の130\%になる地点に印をつけ，その印上 にステップ脚である左足関節が接地するように投げさせ た（Fig. 2).一方で, [通常］におけるステップ幅の平 均值は, 平地では下肢長の $162 \pm 7 \%$, マウンドでは下肢 長の $175 \pm 9 \%$ であった。 なお，下肢長の平均值は $87 \pm 4$ $\mathrm{cm}$ であった。［外］では，基準線(2)から左に $15^{\circ}$ 回転さ せた線を基準点から引き，その線上にステップ脚である 左足関節が接地するように投げさせた（Fig. 2)．［狭い］ および [外］の条件は，被験者が主観的に投げ難いと感 じない範囲で決定した。 なお, 疲労やウォーミングアッ プ効果による影響を考慮し, 試技の順序は被験者毎に変 えた。

動作の分析には，9台の光学式 3 次元自動動作分析装 置（VICON社製）を使用し，サンプリング周波数は250 $\mathrm{Hz}$ とした，反射マーカーは，投球側の第 3 中手骨頭，投 球側の橈 · 尺骨茎状突起, 投球側の上腕骨内 - 外側上顆, 投球側の肩関節前・後面, 両側の肩峰, 胸骨上縁, 第 7 頸椎棘突起, 両側の肋骨下端, 両側の上前腸骨棘, 両側 の上後腸骨棘, 両側の足関節内·外果, 両側の踵部, ボー
ル（両側）の計25点に貼付した（Fig. 4)。マーカー番号 を Fig. 4 に示した点 1 から点25で表すと，右肩関節中心 は点 6 と点 7 の中点, 右肘関節中心は点 4 と点 5 の中点, 右手関節中心は点 2 と点 3 の中点と定義した。 そして, 計測点の座標成分毎に最適遮断周波数を決定し，4 次の ButterWorthを用いて得られた三次元座標を平滑化し た. 最適遮断周波数は, Winter ${ }^{16)}$ の方法を用いて決定し た。計測点の最適遮断周波数の範囲は7-25 Hzであり, ボール中心の鉛直成分の周波数が最も高く $(25 \mathrm{~Hz})$, 左 上前腸骨棘の鉛直成分が最も低かった $(7 \mathrm{~Hz})$. このよ うにして得られた三次元データを基に, 逆動力学解析を 行い，運動学および運動力学的デー夕を算出した ${ }^{17)}$. な お, ボール加速時にボールが手に作用する力を外力とし て計算に用いた。また試技前に，［狭い］と［外］の条 件を設定した線上に反射マーカーを配置させ，設定した 線上の座標值を得ることで，ステップ脚の接地位置と設 定した線との誤差を確認した。 なお, 実験場面ではステッ プ脚の踵（縦は足長の後ろ $1 / 3$, 横は靴幅）が $5 \mathrm{~cm}$ 幅の テープ上に位置し，ボールが的に命中した試技を成功試 技として採用した。

また，本研究で用いた静止座標系は基準点を原点とし た右手系の直交座標系であり，X軸の正は投球方向に対 して右方向， $\mathrm{Y}$ 軸の正は投球方向， $\mathrm{Z}$ 軸の正は鉛直上方 向とした（Fig. 3).

運動座標系の定義 本研究では, 宮西 ${ }^{17,18)}$ によるモデル に基づき，肩関節における上腕骨頭に作用する関節間力 および肩関節の上腕骨に作用する関節トルクを求めた。 宮西 ${ }^{17,18)}$ の方法では，肩関節の運動座標系は上腕を基準 として定義していた。本研究では，肩関節における上腕 骨頭に作用する関節間力および肩関節の内旋卜ルクの算
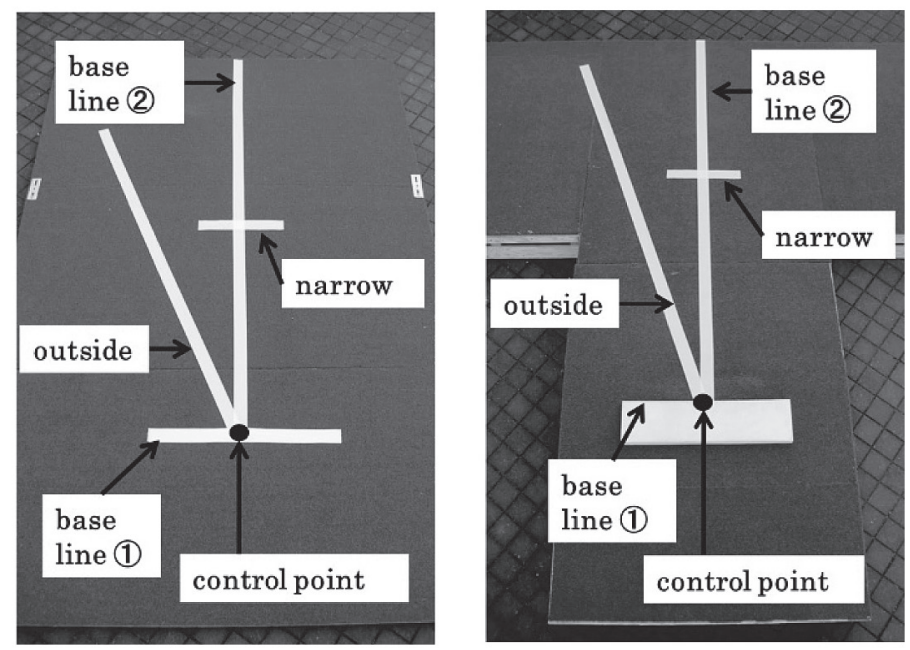

Fig. 2 Pitching movements were provided.

It was provided by putting a tape on each of flat ground and mound conditions. 


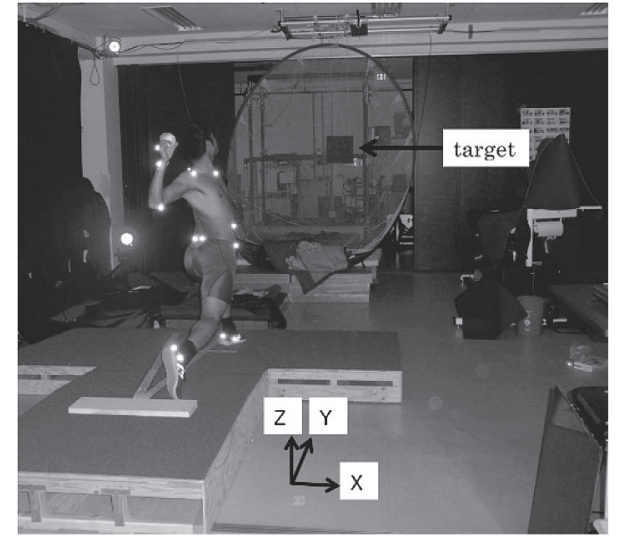

Fig. 3 Setting on the target, experimental landscape. The target was set on the net $4.6 \mathrm{~m}$ ahead.

出を行うために，体幹と上腕の長軸を基準とした運動座 標系を定義した（Fig. 5)。

体幹を基準とした運動座標系では，胸骨上縁と第 7 頸 椎棘突起を結ぶ線の中点から左右胁骨を結ぶ線の中点へ 向かうベクトルを基準軸（Z軸）とし, 胸骨上縁と第 7 頸椎棘突起を結ぶ線の中点から右肩関節中心へ向かうべ クトルとZ 軸のベクトルの外積から，これらに直交する ベクトル（X軸）を求めた。そして，X軸方向を示すべ クトルとZ 軸方向を示すべクトルから残る 1 軸（Y 軸） を決定した，右上腕および右肩関節における運動座標系 では，右肘関節中心から右肩関節中心へ向かうベクトル を基準軸（ $Z$ 軸）とし，右肩関節中心から右肩関節前面 へ向かうベクトルとZ 軸のベクトルの外積から, これら に直交するベクトル（X軸）を求めた。そして，X軸方 向を示すべクトルと Z 軸方向を示すべクトルから残る 1 軸（Y軸）を決定した，右前腕扮よび右肘関節における 運動座標系では, 右手関節中心から右肘関節中心へ向か うベクトルを基準軸（ $Z$ 軸）とし, 右肘関節中心から右 内側上顆へ向かうべクトルとZ 軸のベクトルの外積か ら,これらに直交するべクトル $(\mathrm{X}$ 軸)を求めた。 そして, X軸方向を示すべクトルとZ 軸方向を示すべクトルから 残る1軸（Y軸）を決定した。右手㧍よび右手関節にお ける運動座標系では，右第 3 中手骨頭から右手関節中心 へ向かうベクトルを基準軸（ $\mathrm{Z}$ 軸）とし，右手関節中心 から右尺骨茎状突起へ向かうベクトルと Z 軸のベクトル の外積から,これらに直交するべクトル $(\mathrm{X}$ 軸)を求めた。 そして，X軸方向を示すべクトルとZ 軸方向を示すべク トルから残る 1 軸（Y 軸）を決定した。

ボール速度の算出と的の設置位置の決定 ボール速度 （Vb）は，リリース直後から $0.02 \mathrm{~s} （ 5$ フレーム）後まで の平均速度とした。

的の設置位置は次のようにして決定した。まず，通常
投げの練習投球におけるボールリリース時のボールの座 標值（x,y, z) とボールリリース時の水平 $\mathrm{y}$ 方向のボー ル速度（Vy）を測定した，次にそのボールリリース位置 から y 方向速度 $V y$ のボールが投げられた場合に，目標 とする仮想のホームベース上位置（0, 18.44, 0.7）をボー ルが通過する三次元座標上での放物線軌道を算出した。 そして，その軌道における $\mathrm{y}$ 方向 $4.6 \mathrm{~m}$ 地点に的の中心 を合わせて設置した。

\section{データの算出項目}

A）動作の局面分け

本研究に打ける投球動作の局面は，足底接地加肩関 節最大外旋位をコッキング期, 肩関節最大外旋位から ボールリリース時点までを加速期，ボールリリース時点 以降をフォロースルー期とした ${ }^{19)}$ 。足底接地は，ステッ プ脚である左踵部の Z座標が最低值付近で静止した時点 とした、また, ボールリリース時点は, 第 3 中手骨頭とボー ル中心との距離が, 各被験者の第 3 指の指長（第 3 中手 骨頭から第 3 指の指先）とボール半径 $(4 \mathrm{~cm})$ との和を 超えた最初の時点とした。なお，ボールリリース時点を 基準として, ボールリリース時点より前はマイナス, ボー ルリリース時点より後はプラスの時間で示した。

B）肩関節における関節間力と内旋トルク，肘関節にお ける内反トルク

肩関節に扮ける上腕骨頭に作用する関節間力と内旋卜 ルクは次のように算出した。体幹に抢ける運動座標系に て, X 軸方向に作用する関節間力を前方・後方剪断力, $Z$ 軸方向に作用する関節間力を上方・下方剪断力として 算出した。また，上腕における運動座標系にて， Z 軸方 向に作用する関節間力を近位搴引力， $Z$ 軸回りに作用す る関節モーメントを肩関節内旋トルクとして算出した。 前腕に掞ける運動座標系にて，X軸回りに作用する関節 モーメントを肘関節内反トルクとして算出した。

\section{C）肩関節における関節角度}

肩関節における肩関節外旋，水平屈曲，外転の関節角 度は次のように算出した。肩関節外旋角度は，胸骨上縁 と第 7 頸椎棘突起を結ぶ線の中点と両側の胁骨下端を結 ぶ線の中点を結んだ線を基本軸，右手関節中心と右肘関 節中心を結ぶ線を移動軸として，なす角度とした。肩関 節水平屈曲角度は，両側の肩峰を結ぶ線を基本軸，右肩 関節中心と右肘関節中心を結ぶ線を移動軸として，なす 角度とした。肩関節外転角度は，胸骨上縁と第 7 頸椎棘 突起を結ぶ線の中点と両側の肋骨下端を結ぶ線の中点を 結んだ線を基本軸，右肩関節中心と右肘関節中心を結ぶ 線を移動軸として，なす角度とした。なお，肩関節最大 外旋位掞よびボールリリース時の関節角度とした。 


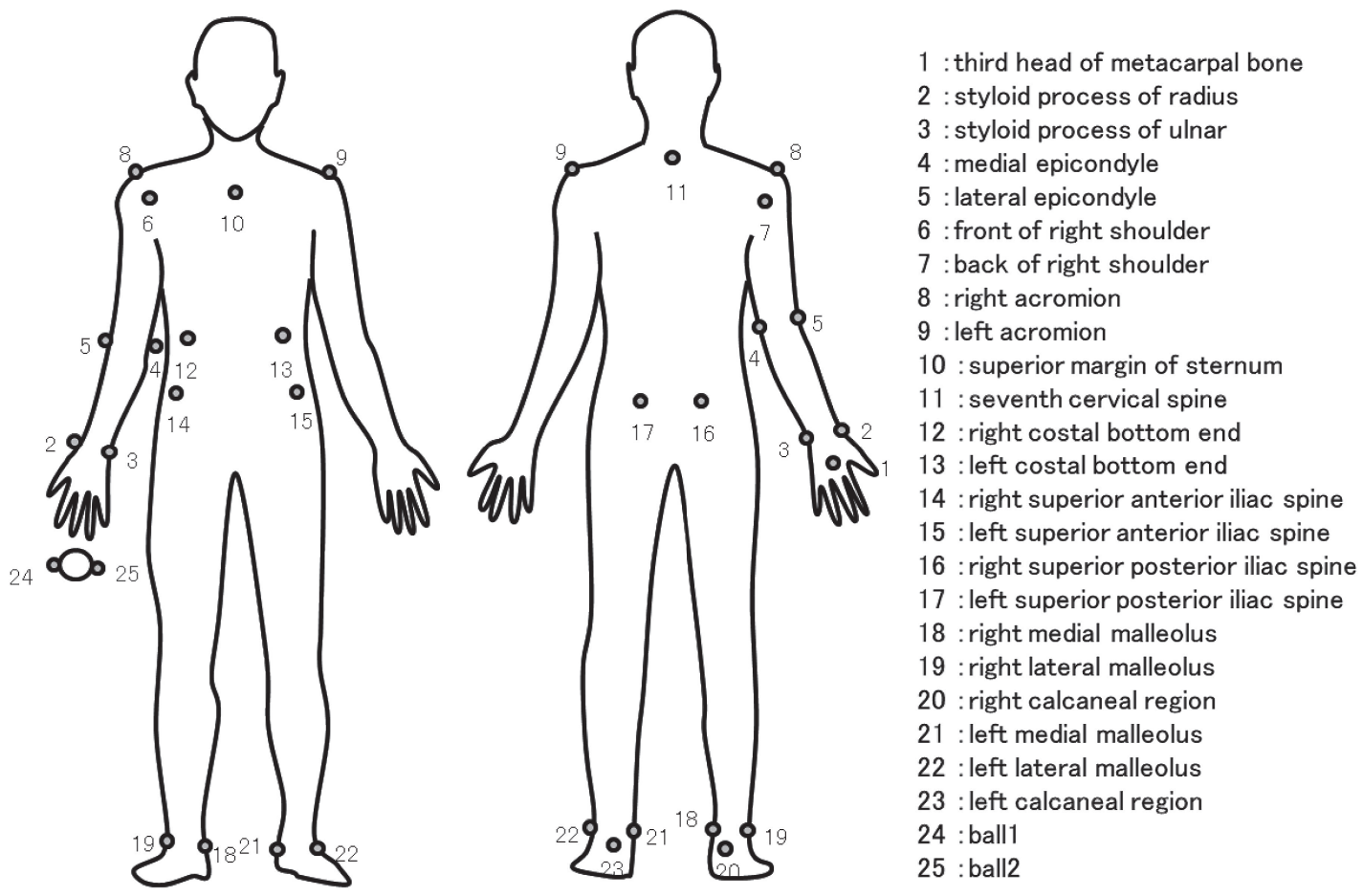

Fig. 4 Position of reflection marker.

The reflection marker was affixed to a total of 25 points of the body and the ball.

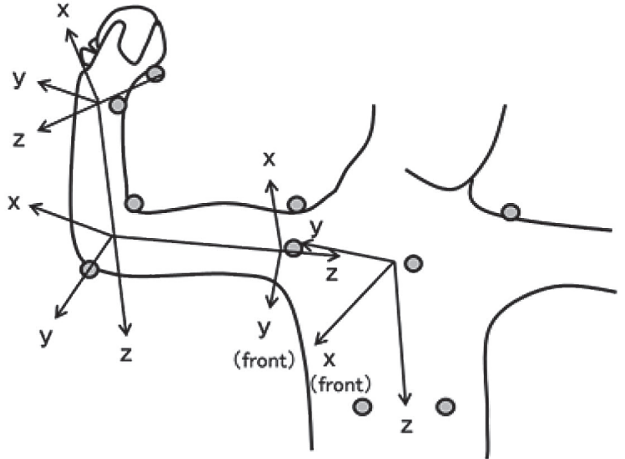

Fig. 5 Motor coordinate system of trunk and upper limb. In order to calculate the internal rotation torque and joint reaction force on the shoulder, a motion coordinate system based on the long axis of the trunk and upper arm was defined.

統計処理 各測定項目について, 環境（平地・マウンド の 2 水準, 対応あり) と動作（通常・狭い・外の 3 水準, 対応あり）を要因とした二元配置分散分析を行い，交 互作用が有意であった場合, 単純主効果の検定を行っ た. 多重比較はボンフェローニ法で行った. 統計処理は, IBM SPSS Statistics21を使用し，有意水準は $5 \%$ とした。

\section{結 果}

ボール速度ボール速度は平地における [通常], [狭い], [外] の順に, $33.8 \pm 2.4 \mathrm{~m} / \mathrm{s}, 32.1 \pm 1.6 \mathrm{~m} / \mathrm{s}, 32.2 \pm 1.9$ $\mathrm{m} / \mathrm{s}$ ，マウンドに扩ける [通常］，[狭い］，［外］の順に， $34.7 \pm 2.5 \mathrm{~m} / \mathrm{s}, \quad 32.5 \pm 1.8 \mathrm{~m} / \mathrm{s}, \quad 33.0 \pm 1.8 \mathrm{~m} / \mathrm{s}$ であった (Table 1)。その中で, 環境拈よび動作の主効果が有意で あり，マウンドは平地よりも，［通常］は［狭い］㧍よび [外］よりも有意に高い值を示した（Table 1).

肩関節における関節間力と内旋トルク，肘関節における 内反トルク 肩関節における上腕骨頭に作用する関節間 力のピーク值において, 前方剪断力は環境および動作の 主効果が有意であり，マウンドは平地よりも，[通常］ は［外］よりも有意に高い值を示した（Table 1)，後方 剪断力は環境および動作の主効果が有意であり, マウン ドは平地よりも, [通常］は［狭い］および［外］より も有意に高い值を示した（Table 1)，上方剪断力は動作 の主効果が有意であり，［通常］は［狭い］拈よび [外 $]$ よりも有意に高い值を示した（Table 1)。下方剪断力は 動作の主効果が有意であり, [通常］は［狭い］および［外］ よりも有意に高い值を示した（Table 1)。近位牽引力は, 環境および動作の主効果とそれぞれの交互作用が有意で あった、マウンドは平地よりも，[通常］は［狭い］抢よ び [外］よりも有意に高い值を示した。また単純主効果 の検定では，[通常］および［外］に打いて，マウンドは 平地よりも有意に高い值を示した（Table 1).

肩関節内旋トルクおよび肘関節内反トルクのピーク值 に拈いて, 動作の主効果が有意であり, [通常］は［狭い］ 
よりも有意に高い值を示した（Table 1）.

\section{足底接地および肩関節最大外旋位, 肩関節間力と肩関節 内旋トルクのピーク值の出現時点 足底接地の出現時点 （足底接地からリリースまでの時間）に扔いて，動作の 主効果が有意であり，[通常］が [狭い］よりも有意に短 い值を示した（Table 2)。一方で，最大外旋位，肩関節 間力と肩関節内旋卜ルク, 肘関節内反トルクのピーク值 の出現時点には, 各条件間で有意な差は認められなかっ た (Table 2).}

肩関節における関節角度 ボールリリース時の肩関節外 旋, 水平屈曲, 外転角度は [通常］が [外］よりも有意 に高い值を示した（Table 3）。その他の関節角度に，有 意差は認められなかった。

\section{考察}

ボール速度 本研究におけるボール速度は, マウンドで の [通常］が $34.7 \mathrm{~m} / \mathrm{s}$ で最高, 平地での [狭い］が32.1 $\mathrm{m} / \mathrm{s}$ で最低であった，大学生を対象とした屋外のマウン ドにて行われた先行研究において，ボール速度は 38.0 $\mathrm{m} / \mathrm{s}^{20)}, 38.3 \mathrm{~m} / \mathrm{s}^{1)}$ が計測されて㧍り, 本研究の值は屋 外のマウンドでの計測值より低かった。一方で，平地に て行われた先行研究では, ボール速度は $29.2 \mathrm{~m} / \mathrm{s}^{17)}$ を計
測しており，本研究の方がボール速度は高かった。また 本研究では，環境を平地とマウンドに，ステップ位置を [通常］［狭い］［外］に分けている，それぞれの条件内 で比較すると, マウンドは平地よりも, [通常］は［狭い］ と［外］よりも，ボール速度が有意に高い值を示した。 蒢山ら ${ }^{21)}$ は, マウンドでの投球は平地よりもストライド 長を大きくすることによって投球速度を増大させている と報告している。ボール速度の結果から, 平地はマウン ドと比較して, [狭い］と［外］は［通常］と比較して, ストライド長が小さいことでボール速度も低くなってい ると考えられた。

\section{肩関節における内旋トルク，时関節における内反トルク}

投球動作中に発生する肩関節における関節トルクは, 特に内旋トルクのピーク值が投球障害肩に影響している と報告されて打り，その值は $67 \mathrm{Nm}^{1)}, 78 \mathrm{Nm}^{8)}$ を示し ている. 本研究に扔ける值は, マウンドでの[通常]にて, $73 \mathrm{Nm}$ とほぼ同等の值を記録しており, ピーク值は先 行研究と同様に最大外旋位の手前 $(-0.05$ から $-0.043 \mathrm{~s}$ 後)で出現した（Table 2)。中村ら ${ }^{22)}$ が，ストレートは カーブより有意にボール速度が高く，肩関節内旋卜ルク はカーブよりストレートの方が高いと報告していること から，ボール速度と肩関節内旋卜ルクは関係していると 考えられる，そして，本研究に打ける肩関節内旋卜ルク

Table 1. Peak value of ball speed, joint torque and joint shearing force.

\begin{tabular}{|c|c|c|c|c|c|}
\hline & & normal & narrow & outside & significant difference \\
\hline \multirow{2}{*}{ bal1 speed $(\mathrm{m} / \mathrm{s})$} & flat ground & $33.8 \pm 2.4$ & $32.1 \pm 1.6$ & $32.2 \pm 1.9$ & $* *:$ mound $>$ flat, normal $>$ outside \\
\hline & mound conditions & $34.7 \pm 2.5$ & $32.5 \pm 1.8$ & $33.0 \pm 1.8$ & $* * *:$ norma $1>$ narrow \\
\hline \multirow{2}{*}{$\begin{array}{l}\text { anterior shearing } \\
\text { force }(\mathrm{N})\end{array}$} & flat ground & $274 \pm 37$ & $263 \pm 28$ & $252 \pm 19$ & $*:$ mound $>$ flat, normal $>$ outside \\
\hline & mound conditions & $280 \pm 34$ & $265 \pm 23$ & $262 \pm 22$ & \\
\hline \multirow{2}{*}{$\begin{array}{l}\text { posterior shearing } \\
\text { force }(\mathrm{N})\end{array}$} & flat ground & $478 \pm 105$ & $434 \pm 91$ & $432 \pm 88$ & $*:$ normal $>$ outside \\
\hline & mound conditions & $501 \pm 104$ & $444 \pm 82$ & $452 \pm 93$ & $* *:$ mound $>$ flat, norma $1>$ narrow \\
\hline \multirow{2}{*}{$\begin{array}{l}\text { superior shearing } \\
\text { force }(\mathrm{N})\end{array}$} & flat ground & $103 \pm 40$ & $78 \pm 42$ & $76 \pm 47$ & $*:$ normal $>$ outside \\
\hline & mound conditions & $102 \pm 47$ & $48 \pm 48$ & $70 \pm 43$ & ** : normal >narrow \\
\hline \multirow{2}{*}{$\begin{array}{l}\text { inferior shearing } \\
\text { force }(\mathrm{N})\end{array}$} & flat ground & $453 \pm 131$ & $404 \pm 101$ & $389 \pm 78$ & $*:$ normal $>$ outside \\
\hline & mound conditions & $481 \pm 111$ & $399 \pm 83$ & $395 \pm 78$ & $* *:$ normal $>$ narrow \\
\hline \multirow{2}{*}{$\begin{array}{l}\text { proximal traction } \\
\text { force }(\mathrm{N})\end{array}$} & flat ground & $692 \pm 125$ & $647 \pm 115$ & $624 \pm 113$ & $* *$ : mound $>$ flat, normal $>$ narrow $\cdot$ outsid \\
\hline & mound conditions & $726 \pm 135$ & $652 \pm 115$ & $642 \pm 111$ & normal $\cdot$ outside $:$ mound $>$ flat \\
\hline \multirow{2}{*}{$\begin{array}{l}\text { shoulder internal } \\
\text { rotation }(\mathrm{N} \cdot \mathrm{m})\end{array}$} & flat ground & $72.4 \pm 13$ & $67.0 \pm 11$ & $68.2 \pm 10$ & $* *$ : norma1 $>$ narrow \\
\hline & mound conditions & $73.0 \pm 15$ & $66.9 \pm 9.8$ & $69.0 \pm 9.8$ & \\
\hline \multirow{2}{*}{$\begin{array}{l}\text { elbow varus } \\
(\mathrm{N} \cdot \mathrm{m})\end{array}$} & flat ground & $73.2 \pm$ & $66.8 \pm 13$ & $69.7 \pm 11$ & $*:$ normal $>$ narrow \\
\hline & mound conditions & $75.9 \pm$ & $66.6 \pm 9.1$ & $70.7 \pm 9.5$ & \\
\hline
\end{tabular}

The pitching velocity was significantly higher in the [normal] compared with [narrow] and [outside] conditions and under the mound compared with flat ground condition. The peak torque of the shoulder internal rotation was significantly higher in the [normal] compared with [narrow]. The peak torque of the elbow varus was significantly higher in the [normal] compared with [narrow]. The posterior, superior, and inferior shearing forces, as well as the proximal traction force, which influence the humeral head of the shoulder, were markedly greater in the [normal] compared with [narrow] and [outside] conditions. The anterior and posterior shearing forces and proximal traction force were significantly greater under the mound compared with flat ground conditions. average \pm standard deviation ${ }^{*}: \mathrm{p}<0.05,{ }^{* *}: \mathrm{p}<0.01,{ }^{* * *}: \mathrm{p}<0.001$ 
Table 2. The time of foot contact and the appearance time of maximum external rotation, peak torque and peak shearing force in the shoulder joint.

\begin{tabular}{|c|c|c|c|c|c|c|c|c|}
\hline & & \multicolumn{2}{|l|}{ normal } & \multicolumn{2}{|c|}{ narrow } & \multicolumn{2}{|c|}{ outside } & \multirow{2}{*}{$\frac{\text { significant difference }}{* *: \text { normal }>\text { narrow }}$} \\
\hline \multirow{2}{*}{ foot contact (s) } & flat ground & $-0.141 \pm$ & 0.039 & $-0.162 \pm$ & 0.031 & $-0.151 \pm$ & 0.033 & \\
\hline & mound conditions & $-0.131 \pm$ & 0.026 & $-0.162 \pm$ & 0.035 & $-0.146 \pm$ & 0.026 & \\
\hline \multirow{2}{*}{$\begin{array}{l}\text { shoulder maximum } \\
\text { external rotation } \\
(\mathrm{s})\end{array}$} & flat ground & $-0.061 \pm$ & 0.003 & $-0.063 \pm$ & 0.003 & $-0.063 \pm$ & 0.003 & \\
\hline & mound conditions & $-0.060 \pm$ & 0.003 & $-0.062 \pm$ & 0.002 & $-0.062 \pm$ & 0.003 & \\
\hline \multirow{2}{*}{$\begin{array}{l}\text { anterior shearing } \\
\text { force }(\mathrm{s})\end{array}$} & flat ground & $-0.094 \pm$ & 0.011 & $-0.097 \pm$ & 0.011 & $-0.093 \pm$ & 0.013 & \\
\hline & mound conditions & $-0.090 \pm$ & 0.010 & $-0.092 \pm$ & 0.011 & $-0.088 \pm$ & 0.013 & \\
\hline \multirow{2}{*}{$\begin{array}{l}\text { posterior shearing } \\
\text { force }(\mathrm{s})\end{array}$} & flat ground & $0.068 \pm$ & 0.004 & $0.068 \pm$ & 0.005 & $0.071 \pm$ & 0.004 & \\
\hline & mound conditions & $0.068 \pm$ & 0.003 & $0.067 \pm$ & 0.003 & $0.069 \pm$ & 0.002 & \\
\hline \multirow{2}{*}{$\begin{array}{l}\text { superior shearing } \\
\text { force }(\mathrm{s})\end{array}$} & flat ground & $-0.092 \pm$ & 0.024 & $-0.099 \pm$ & 0.027 & $-0.089 \pm$ & 0.030 & \\
\hline & mound conditions & $-0.085 \pm$ & 0.016 & $-0.100 \pm$ & 0.021 & $-0.087 \pm$ & 0.026 & \\
\hline \multirow{2}{*}{$\begin{array}{l}\text { inferior shearing } \\
\text { force }(\mathrm{s})\end{array}$} & flat ground & $0.024 \pm$ & 0.005 & $0.024 \pm$ & 0.004 & $0.027 \pm$ & 0.005 & \\
\hline & mound conditions & $0.024 \pm$ & 0.003 & $0.023 \pm$ & 0.004 & $0.027 \pm$ & 0.003 & \\
\hline \multirow{2}{*}{$\begin{array}{l}\text { proximal traction } \\
\text { force }(\mathrm{s})\end{array}$} & flat ground & $0.002 \pm$ & 0.005 & $0.001 \pm$ & 0.005 & $0.002 \pm$ & 0.004 & \\
\hline & mound conditions & $0.002 \pm$ & 0.004 & $0.001 \pm$ & 0.004 & $0.001 \pm$ & 0.005 & \\
\hline \multirow{2}{*}{$\begin{array}{l}\text { shoulder internal } \\
\text { rotation }(\mathrm{s})\end{array}$} & flat ground & $-0.046 \pm$ & 0.003 & $-0.046 \pm$ & 0.003 & $-0.047 \pm$ & 0.003 & \\
\hline & mound conditions & $-0.046 \pm$ & 0.003 & $-0.047 \pm$ & 0.003 & $-0.046 \pm$ & 0.003 & \\
\hline \multirow{2}{*}{ elbow varus (s) } & flat ground & $-0.038 \pm$ & 0.005 & $-0.037 \pm$ & 0.005 & $-0.037 \pm$ & 0.006 & \\
\hline & mound conditions & $-0.038 \pm$ & 0.005 & $-0.037 \pm$ & 0.006 & $-0.037 \pm$ & 0.005 & \\
\hline
\end{tabular}

The time of foot contact was significantly shorter in the [normal] compared with [narrow]. On the other hand, there were no significant differences in the appearance time of maximum external rotation, peak torque and peak shearing force among stepping conditions.

average \pm standard deviation ${ }^{* *}: \mathrm{p}<0.01$,

Table 3. Joint angle in the shoulder joint.

\begin{tabular}{|c|c|c|c|c|c|}
\hline & & normal & narrow & outside & significant difference \\
\hline \multicolumn{6}{|l|}{ MER } \\
\hline \multirow{2}{*}{$\begin{array}{l}\text { external rotation } \\
\text { angle }\left({ }^{\circ}\right)\end{array}$} & flat ground & $167 \pm 21$ & $166 \pm 19$ & $161 \pm 18$ & \\
\hline & mound conditions & $168 \pm 18$ & $168 \pm 17$ & $161 \pm 18$ & \\
\hline \multirow{2}{*}{$\begin{array}{c}\text { horizontal } \\
\text { flexion/extension } \\
\text { angle }\left(^{\circ}\right)\end{array}$} & flat ground & $2.6 \pm 5.6$ & $2.5 \pm 6.0$ & $2.7 \pm 6.2$ & \\
\hline & mound conditions & $3.1 \pm 5.6$ & $2.6 \pm 5.9$ & $1.6 \pm 5.9$ & \\
\hline \multirow{2}{*}{$\begin{array}{c}\text { abduction angle } \\
\left({ }^{\circ}\right)\end{array}$} & flat ground & $103 \pm 8.1$ & $105 \pm 7.4$ & $103 \pm 6.8$ & \\
\hline & mound conditions & $104 \pm 5.6$ & $105 \pm 8.2$ & $103 \pm 6.6$ & \\
\hline \multicolumn{6}{|l|}{ BRL } \\
\hline \multirow{2}{*}{$\begin{array}{l}\text { external rotation } \\
\text { angle }\left({ }^{\circ}\right)\end{array}$} & flat ground & $60 \pm 9.0$ & $57 \pm 9.3$ & $52 \pm 9.0$ & $* *:$ normal $>$ outside \\
\hline & mound conditions & $60 \pm 7.0$ & $58 \pm 9.0$ & $51 \pm 9.0$ & \\
\hline \multirow{2}{*}{$\begin{array}{l}\text { horizontal flexion } \\
\quad \text { angle }\left({ }^{\circ}\right)\end{array}$} & flat ground & $9.1 \pm 8.5$ & $7.2 \pm 8.0$ & $4.5 \pm 8.2$ & $*:$ normal > outside \\
\hline & mound conditions & $9.4 \pm 7.2$ & $6.6 \pm 7.1$ & $4.2 \pm 7.2$ & \\
\hline \multirow{2}{*}{$\begin{array}{c}\text { abduction angle } \\
\left({ }^{\circ}\right)\end{array}$} & flat ground & $108 \pm 5.9$ & $106 \pm 6.2$ & $103 \pm 5.4$ & **: normal >outside \\
\hline & mound conditions & $108 \pm 5.0$ & $105 \pm 4.6$ & $102 \pm 4.5$ & \\
\hline
\end{tabular}

The external rotation angle at BRL was significantly higher in the [normal] compared with [outside] conditions. The horizontal flexion angle at BRL were significantly higher in the [normal] compared with [outside] conditions. The abduction angle at BRL was significantly higher in the [normal] compared with [outside] conditions. average \pm standard deviation ${ }^{*}: \mathrm{p}<0.05,{ }^{* *}: \mathrm{p}<0.01$

MER: maximum external rotation BRL: ball release

のピーク值は，[狭い］が［通常］よりも有意に低い值 を示した（Table 1)。この要因として，[狭い］は［通常］ と比較すると, ストライド長が小さいことに伴い, ボー ル速度が低かったためと考えられた。また，平地とマウ ンドや $[$ 通常 $]$ と [外] では差が認められなかった。宮永
ら ${ }^{23)}$ は, 踏み出した足が極端にオープンに着地した場合 は, 腰の回転が早く起こりすぎると報告している。また, 投球時に生じる体幹の回旋が遅いと肩関節内旋卜ルクは 低くなると言われている8)。このことから，[外］では 早期の腰の回転に伴い体幹の回旋が早くなり, 肩関節内 
旋トルクが高くなりやすいと考えられた，そのため，本 研究における平地や [外] ではボール速度が低いにも関 わらず，マウンドや [通常］と同じぐらい肩関節内旋卜 ルクが高くなり, 肩関節内旋トルクによる肩関節への負 荷が生じていると考えられた。また肩関節内旋卜ルクの ピーク值は，全ての条件において加速期（最大外旋位か らボールリリースの間）に出現していた（Table 2)。後期 コッキング期（足底接地から最大外旋位）から加速期に かけて生じる肩関節外旋運動は, 身体の近位部に対して 遠位部が遅れる現象によって生じると言われている7,13). 本研究の結果にて, [外］は［通常］よりも肩関節最大 外旋位拉よびボールリリース時の肩関節外旋角度が低い ことからも, 局関節外旋運動が生じ難くなり, ボール速 度の割に肩関節内旋卜ルクが増大することで肩関節外旋 から内旋への切り替えを行っていると考えられる.また, 䔖山ら ${ }^{21)}$ の報告によると, 投球動作中に扮ける身体重心 の合成速度は，平地はマウンドょりも低くなる，そのた め, 並進運動に関して, 平地はマウンドよりも不利であ ると考えられる。これらにより，[外] や平地では身体の 開きを早くすることで，より回転運動を利用して動作を 遂行していると考えられた。

他方で，投球動作中に発生する时関節内反トルクは， 肩関節の外旋運動が影響していると報告されており ${ }^{13)}$, Fleisig et al. ${ }^{1}{ }^{1}$ は肩関節内旋トルクの值が $67 \mathrm{Nm}$ に対し, 肘関節内反トルクの值は64 $\mathrm{Nm}$ とほぼ同等の值を示し ている，本研究における值は，マウンドでの［通常］に て, 肩関節内旋トルクの值が $73 \mathrm{Nm}$ に対し, 肘関節内反 トルクの值は $76 \mathrm{Nm}$ と同等の值を記録した。そそのため, 肩関節と肘関節に生じる負荷は, 関連している可能性が あると考えられた。

肩関節における関節間力 次に, 肩関節に抢ける上腕骨 頭に作用する関節間力について考える.この関節間力は, 前方・後方・上方・下方の剪断力と近位の星引力に分け られる。 まず前方剪断力について，マウンドが平地より も, [通常 $]$ が [外]よりも, 有意に高い值を示した（Table 1). ボール速度も同様の結果を示していることから, ボー ル速度が高い方が前方剪断力による負荷は生じやすい可 能性が考えられた。一方で，[狭い］は［通常］と比較し て有意な差が認められなかったことから，ボール速度が 低い割に，[通常］と同じぐらいの前方剪断力による肩 関節への負荷が生じていると考えられた。また，前方剪 断力のピーク值は, 全ての条件に扔いて, 足底接地から 最大外旋位の間で出現していた（Table 2)。後期コッキ ング期から加速期に発生しやすい肩関節前面の疾患とし て, 前方関節唇損傷や腱板疎部損傷があり，上腕骨頭が 肩甲骨関節窩に対し前方に変位することが発生要因の一 つと言われている ${ }^{6)}$ ，このため, 前方剪断力は肩関節前
面の軟部組織により, 上腕骨頭が前方へ牽引される力に よって発生すると考えられた，今回の結果を，生成され る力の観点から考えると，マウンドよりも平地，[通常］ よりも [外] の条件の方が投球障害肩は発生し難いこと になる。しかし，ボールリリース時の肩関節水平屈曲角 度は, [通常 $]$ が [外 $]$ よりも有意に高い值を示した。中 村ら ${ }^{2)}$ はボールリリース時の肩関節水平屈曲角度は $10^{\circ}$ 前後が最も肩関節の負荷が少ないと報告している，本研 究は, [通常] が $9^{\circ}$ と同等の值を認めていたが，[外］は それよりも低い值であった。そのため，投球フォームに 関しては［外］よりも [通常］の条件の方が投球障害肩 は発生し難いことになる。

後方剪断力については, マウンドが平地よりも, [通常] が［狭い］と［外］よりも有意に高い值を示した，ボー ル速度も同様の結果を示して㧍り，ボール速度が高い方 が上肢の振りは速くなるため, その分の制動力が必要で あるためではないかと考えられた，今回の結果を，発生 する力の観点から考えると, マウンドよりも平地の方が, [通常］よりも [狭い］と［外］の方が投球障害肩は発生 し難いと考えられる. また, 後方剪断力のピーク值は, 全ての条件において, ボールリリース以降に出現してい た（Table 2)。ボールリリース以降の時期には，肩関節 内旋運動に伴い，上腕の末梢端は肩関節よりも前方に位 置し，肩関節後方の筋群は肩関節の前方への剪断力に対 抗するために重要な役割を果たしている ${ }^{23)}$ 。 また，同時 期に発生しやすい肩関節後面の疾患として，後方関節包 炎や棘下筋炎があり ${ }^{6)}$, 後方剪断力は前方へ向かう上腕 を肩関節後面の軟部組織が後方へ引っ張ることによって 発生すると考元られる。

上方剪断力については，［通常］が［狭い］と［外］よ りも有意に高く（Table 1)，ボール速度による影響が大 きいのではないかと考えられた，下方剪断力については， [通常］が［狭い］と［外］よりも有意に高い值を示した (Table 1).ボール速度も同様の結果を示しており,ボー ル速度が高い方が上肢の振りは速くなるため, その分の 制動力が必要であるためではないかと考えられる。ま た, 下方剪断力のピーク值は, 全ての条件において, ボー ルリリース以降の時期を示していた（Table 2)。ボール リリース直後は，肩関節内転抒よび内旋運動に伴い，上 腕の中枢端は肩関節に対して上方へ移動しようとするた め, 下方剪断力は上腕の中枢端が上方へ移動しょうとす るのを下方へ引っ張ることによって発生すると考えられ た，今回の結果を，発生する力の観点から考えると，[通 常］よりも [狭い］と［外］の方が投球障害肩は発生し 難いと考えられた。

近位挛引力については，[通常］が［狭い］と［外］ よりも，マウンドが平地よりも有意に高い值を示した (Table 1).ボール速度も同様の結果を示しており, ボー 
ル速度が高い方が上肢の振りが速くなるためではないか と考えられた。また，近位牵引力のピーク值は，全ての 条件において，ボールリリース直後の時期を示していた (Table 2). このことから, 近位牽引力はボールリリー ス直後に上腕が遠位へ引つ張られるのを引き戻すことに よって発生すると考えられた。

[通常］と [狭い］の肩関節における関節角度は, 変化 がみられなかった。一方で, 後方・上方・下方の剪断力 と近位牽引力は, [通常］が［狭い］よりも有意に高い值 を示した。この結果を臨床に応用すると, リハビリテー ションの場面で段階的に負荷を上げていく際には，ス テップ幅を [狭い] 位置から始めて徐々に広げていくこ とで，肩関節への負荷が小さい動作から段階的に進め, 障害予防に役立つと考えられた。

\section{結＼cjkstart論}

本研究の目的は, 平地とマウンドにおいて投球動作の ステップ脚における接地位置の違いが, 肩関節の負荷に 与える影響を検討することで，投球障害肩の予防に役立 つ知見を得ることであった。 その結果, 以下の知見が得 られた

(1)ボール速度は, [通常］が [狭い] と［外］よりも，マ ウンドが平地よりも有意に高い值を示した。

(2)肩関節内旋トルクのピーク值は, [狭い] が [通常 $]$ よ りも有意に低い值を示した。一方で，［通常］と［外］ や平地とマウンドでは有意差が認められなかった。

(3)肩関節の上腕骨頭に作用する後方・上方 · 下方の剪断 力と近位牽引力は, [通常 $]$ が [狭い] と [外 $]$ よりも 有意に高い值を示した。一方で，前方・後方の剪断力 と近位牽引力は, マウンドが平地よりも有意に高い值 を示したが，上方・下方の剪断力と［狭い］の近位牵 引力には有意差が認められなかった。

以上のことから，ステップ脚における接地位置の違い および平地とマウンドの違いが, 肩関節内旋トルクおよ び肩関節における上腕骨頭に作用する剪断力と牽引力に 影響することが定量的に明らかとなった．今回の結果よ り，負荷が加わる方向によっては，ボール速度が低い条 件であってもボール速度が高い条件と同等の負荷が肩関 節に生じることが分かった。その中でも，[外]では肩関 節内旋トルクによる肩関節への負荷が, 平地では上方・ 下方剪断力による肩関節への負荷が, ボール速度の割に 大きくなることが分かった，今回の知見により，投球動 作のステップ脚における接地位置の違いは, 投球障害肩 を予防するための着眼点の一つと考えられる。

利益相反自己申告：申告すべきものはなし

\section{参 考文献}

1) Fleisig GS, Andrews JR, Dillman CJ, Escamilla RF. Kinetics of baseball pitching with implications about injury mechanisms. Am J Sports Med 23: 233-239, 1995.

2）中村康雄, 林 豊彦, 中村真理, 中溝寛之, 信原克哉, 加藤 直, 飯塚大輔：投球フォームとボール・リリース時の肩 関節負荷, バイオメカニズム, 17: 123-132, 2004.

3）車谷 洋, 村上恒二, 金子文成, 山崎和博：肩関節外旋筋 群の疲労が肩関節へ与える力学的変化に関する研究preliminary studyー, 日本臨床スポーツ医学会誌, 15: 420-428, 2007.

4）田中 洋, 立花 孝, 大井雄紀, 二宮祐樹, 駒井正彦, 信原克 哉, 林 豊彦, 佐志隆士 : 投球動作のバイオメカニクスと 運動連鎖 投球動作のバイオメカニクスと投球障害, 臨 床スポーツ医学, 29: 47-54, 2012.

5）宮西智久, 宮永 豊, 福林 徹, 馬見塚尚孝, 藤井範久, 阿江 通良, 功力靖雄, 岡田守彦：投球動作における肘・肩関 節の 3 次元動力学的研究 - 投球上肢の運動パターン と障害発生の可能性と関連 -, 体力科学, 48: 583-596, 1999.

6）信原克哉. 肩 その機能と臨床 第 4 版, 医学書院, 349395, 2012

7）宮下浩二：投球動作のバイオメカニクスと運動連鎖 運 動連鎖から見た投球動作, 臨床スポーツ医学, 29: 55-60, 2012.

8) Aguinaldo AL, Buttermore J, Chambers H. Effects of upper trunk rotation on shoulder joint torque among baseball pitchers of various levels. J Appl Biomech 23: 42-51, 2007.

9）松尾知之, 平野裕一, 川村卓：投球動作指導における着 眼点の分類と指導者間の意見の共通性；プロ野球投手 経験者および熟練指導者による投球解説の内容分析か ら, 体育学研究, 55: 343-362, 2010.

10) Davis JT, Limpisvasti O, Fluhme D, Mohr KJ, Yocum LA, Elattrache NS, Jobe FW. The effect of pitching biomechanics on the upper extremity in youth and adolescent baseball pitchers. Am J Sports Med 37: 14841491, 2009.

11）川島 堅. 野球肩・野球ひじを治す本, 株式会社マキノ出 版, 152, 2004 .

12）坂田 淳：投球動作の見方と修正, Sportsmedicine 167: 35-38, 2015.

13）宮西智久. 野球のピッチング - キネティクス -, バイオ メカニクス 身体運動の科学的基礎, 杏林書院, 268-277, 2004.

14）法所遼汰, 西脇秀太朗, 淵本隆文：投球動作のステップ 脚における接地位置の違いが肩関節の負荷に与える影 響 - 平地での検討 - , 大阪体育学研究, 56: 29-38, 2018.

15）日本プロフェッショナル野球組織, 全日本野球協会. 公 認野球規則 2016 Official Baseball Rules, ベースボール マガジン社, 2: 200, 2016.

16) Winter DA. Biomechanics and motor control of human movement (2nd ed.). John Wiley and Sons, Inc., 41-43, 1990.

17）宮西智久：剛体リンク系における身体運動の 3 次元関 節トルク算出法の実際, 仙台大学紀要, 30: 46-56, 1998. 
18）宮西智久, 藤井範久, 阿江通良, 功力靖雄, 岡田守彦: 野 球の投球動作におけるボール速度に対する体幹および 投球腕の貢献度に関する 3 次元的研究, 体育学研究, 41 : 23-37, 1996.

19) Jobe FW, Tibone JE, Perry J, Moynes D. An EMG analysis of the shoulder in throwing and pitching. A preliminary report. Am J Sport Med 11: 3-5, 1983.

20) Dillman CJ, Fleisig GS, Andrews JR. Biomechanics of pitching with emphasis upon shoulder kinematics. $J$ Orthop Sports Phys Ther 18: 402-408, 1993.

21）苲山雅洋, 鈴木智晴, 藤井雅文, 中本浩揮, 和田智仁, 前
田明：野球投手におけるマウンドと平地からの投球の バイオメカニクス的比較：投球速度および投球動作中 の下肢および体幹の動作に着目して, 体育学研究, 61: 517-535, 2016.

22）中村康雄, 林 豊彦：ストレートとカーブの投球動作の 運動学・動力学解析, 同志社スポーツ健康科学, 2: 3846, 2010.

23) 宮永 豊：スポーツ科学・医学大辞典 スポーツ運動科 学ーバイオメカニクスと生理学 -, 西村書店, 482-500, 2010. 